Bull. Fac. Agric., Cairo Univ., 70: 31-41 (2019).

\title{
PHOSPHORUS FRACTIONS IN SOIL AMENDED BY MANURE, INORGANIC AND BIO NITROGEN FERTILIZERS UNDER VARIOUS INCUBATION PERIODS
}

(Received: 28.3.2019)

\author{
By \\ M. Y. Khalafalla and Y. A. Sayed \\ Soils and water Department, Faculty of Agriculture, Al-Azhar University, Assuit, Egypt.
}

\begin{abstract}
The peril of phosphorus wastage from manured soils is more related to phosphorus fraction than the total phosphorus concentration in manure. Biogeochemical change of different forms of organic and inorganic phosphorus controls soil phosphorus availability. This study aimed to assess the impact of different nitrogen fertilizers (slow or fast release mineral, organic and bio) under various incubation periods $(14,30$ and 60 days) on soil phosphorus forms. Under treatment of fast release nitrogen + organic + bio fertilizers (FOB), total and organic $\mathrm{P}$ increased by increasing incubation period to one month, then decreased when the incubation period reached two months. The inorganic $\mathrm{P}$ decreased as the incubation period increased while the opposite trend was noticed for available P. The treatments of slow release nitrogen + organic + bio fertilizers (SOB), fast release nitrogen + organic fertilizers (FO) and slow release nitrogen + organic fertilizers $(\mathrm{SO})$ realized an increase in both total and organic $\mathrm{P}$ by increasing the incubation period. As the incubation period increased, the SOB, FO and SO treatments decreased the inorganic $\mathrm{P}$ while the available $\mathrm{P}$ remained almost constant. Under the $\mathrm{OB}$ treatment (organic + bio fertilizers), both total and organic $\mathrm{P}$ were decreased as the incubation period increased. The inorganic $\mathrm{P}$ changed slightly and the available $\mathrm{P}$ increased by increasing the incubation period. After 14 days of incubation period, the low values of $\mathrm{C}: \mathrm{P}$ ratio (28-30) that resulted from $\mathrm{OB}$ and $\mathrm{C}$ treatments maximized the values of available $\mathrm{P}(35.51-36.85 \mathrm{ppm})$, organic $\mathrm{P}(247.1-258.8 \mathrm{ppm})$ and total $\mathrm{P}(314.9-331.0$ $\mathrm{ppm})$, while reduced the value of inorganic $\mathrm{p}(67.84-72.19 \mathrm{ppm})$ and the opposite trend was true. After one month incubation period, a decrease in $\mathrm{C}: \mathrm{P}$ ratio with $\mathrm{FO}, \mathrm{SO}$ and $\mathrm{OB}$ treatments was erved. The highest values of both total $\mathrm{P}(351.8 \mathrm{ppm})$ and available $\mathrm{P}(40.1 \mathrm{ppm})$ were recorded at $\mathrm{C}: \mathrm{P}$ ratio value of 29. The least values of both total $P(197.7 \mathrm{ppm})$ and available $P(18.2 \mathrm{ppm})$ were recorded at $47 \mathrm{C}: \mathrm{P}$. After two month of incubation period, C:P ratios were less than those at 14 and 30 days incubation period under all soil treatments. Available $\mathrm{P}$ increased as the C:P ratio increased. The highest values of C:P ratio (35) was recorded at (41.94 $\mathrm{ppm}$ ) available $\mathrm{P}$ value that resulted from FOB treatment. While, the least values of C: P ratio (28) was recorded at $(26.1 \mathrm{ppm})$ available $\mathrm{P}$ value that resulted from FO treatment. It was noticed that the lowest $\mathrm{C}: \mathrm{P}$ ratio and the highest value of available $\mathrm{P}$ were recorded under $\mathrm{OB}$ treatment.
\end{abstract}

Keywords: labile organic P; soil organic matter; available P; nitrogen fertilizer.

\section{INTRODUCTION}

Phosphorus $(\mathrm{P})$ is one of the fundamental macronutrients which are imperative in numerous procedures for energy and production. Soils contain inorganic and or organic phosphorus which is considered the essential sources of phosphorus to plants. A chief fraction of $\mathrm{P}$ existing in soil is not willingly available to plants and its inadequacy is an imperative to plant development around the world, especially in arid and semi-arid regions. Organic phosphorus (OP) amount varies but often comprises a big fraction of the total phosphorus amount in soil. OP can be changed through enzymatic responses, or absorbed straightforward by microorganisms. By this manner, $\mathrm{P}$ pool is exceptionally dynamic in forms 
that influence both plant take-up and phosphorus misfortunes. Tillage can affect the mineralization and decomposition of soil organic matter (SOM) by changing the physical and chemical properties of soils and altering the diversity and activity of the soil microbial community and enzymes, which in turn affects the concentration and composition of soil P (Frossard et al., 2000; Quiquampoix and Mousain, 2005; Richardson et al., 2005; Turner et al., 2005; Khan and Joergensen, 2009 and Redel et al., 2011).

Phosphorus forms a relevant strategy to decide the phosphorus status of soils and to study the chemistry and genesis of soils (Cross and Schlesinger, 1995). Accurate exactly characterizing phosphorus forms are essential to creating viable remediation procedures to limit the antagonistic environmental effect of farming extension. Information of phosphorus fraction is imperative for assessment its status in soil and understanding soil chemical properties that influence soil richness and ecological quality. Soil phosphorus fractionation has been explored since 1957, and was later connected to soils and sediments to overcome the constrained data that total phosphorus analysis can give (Zhou et al., 2001).

Soils contain inorganic $\mathrm{P}\left(\mathrm{P}_{\mathrm{i}}\right)$ and organic $\mathrm{P}$ $\left(\mathrm{P}_{\mathrm{o}}\right)$ compounds that are important $\mathrm{P}$ sources for plants, but Po rarely represents a major portion of soil P. In a research with tropical forest soils, the Po fraction represented $26 \pm 1 \%$ of total $\mathrm{P}$, distributed in phosphate monoesters (68-96\%), such as mononucleotides and in acetone phosphate, and phosphate diesters (4-32 \%), mainly in the form of nucleic acids and phospholipids. In natural or agricultural ecosystems on low P soils, Po mineralization is the main source of $\mathrm{P}$ supply to plants, especially in highly weathered tropical soils. Organic fertilization influences the $\mathrm{P}$ availability directly and indirectly. The direct impacts contain: $\mathrm{Pi}$ release by organic compound mineralization or microbial immobilization of soil $\mathrm{Pi}$, depending on the $\mathrm{C}: \mathrm{P}$ ratio; rivalry among organic acid anions and phosphate anions for adsorption sites. Such procedures can be managed by the proportion of soil organic carbon and available phosphorus amount. In higher C:P conditions microorganisms have a net immobilization impact on soil phosphorus while in lower C:P state they have a net mobilization effect. Therefore, adding organic $\mathrm{C}$ to the soil can increase the ratio of $\mathrm{C}: \mathrm{P}$ and has been demonstrated to increase microbial biomass phosphorus (MBP) and accordingly diminish plant-available phosphorus, (Stevenson, 1986; Hue et al., 1994; Chen et al., 2000; Guppy et al., 2005; Marschner, 2008; Vincent et al., 2010 and Turner \& Engelbrecht, 2011).

Time is an essential factor for $(\mathrm{Pi})$ changes in the soil and the available phosphorus part, as well as for organic phosphorus (Po) changes. With respect to Po, after the rapid initial phase of decomposition of organic residues applied to the soil, when $\mathrm{P}$ release and available $\mathrm{P}$ increases, it is expected that more stable (or recalcitrant) Po fractions could remain in the soil, and that part of the labile Po is converted to non-labile Po. In a soil incubation trial in laboratory, the application of swine manure caused an initial increase of water-soluble $\mathrm{P}$ concentrations, but after 16 weeks of incubation, water soluble $\mathrm{P}$ decreased with simultaneous increase of the $\mathrm{P}-\mathrm{NaHCO}_{3}$ fraction. Also, the utilization of cattle manure decreased soluble $\mathrm{P}$, while other more stable $\mathrm{P}$ forms expanded, suggesting that microorganisms changed labile-Pi into Po, due to the higher amount of grass residues and higher $\mathrm{C}: \mathrm{P}$ ratio in the manure (Kashem et al., 2004).

The current study aimed to assess the impact of different nitrogen fertilizers (slow or fast release mineral), organic and bio on soil phosphorus forms and to increase knowledge about organic phosphorus in soils under various incubation periods.

\section{MATERIALS AND METHODS}

Surface soil samples $(0-30 \mathrm{~cm})$ were collected from scatter points at The Experimental Farm, Fac. of Agric., Al-Azhar Univ., Assiut, located $375 \mathrm{~km}$ south of Cairo, Egypt (27 $17^{-} 16.67^{=} \mathrm{N}$ latitude and $31^{\circ} 09^{-} 36.86^{=} \mathrm{E}$ longitude). The soil samples were air dried, crashed and sieved through a $2 \mathrm{~mm}$ sieve. Then all soil samples were mixed well to form one composite sample. The soil sample was subjected to some chemical and physical analysis according to Page et al. (1982) and Klute (1986) as shown in Table $(1 \mathrm{a} \& \mathrm{~b})$. 
Table (1): Some physical and chemical properties of the tested soil: a-Physical properties

\begin{tabular}{|c|c|c|c|c|c|c|c|}
\hline \multicolumn{3}{|c|}{ Particles size percentage } & \multirow{2}{*}{$\begin{array}{l}\text { Texture } \\
\text { class }\end{array}$} & \multicolumn{2}{|c|}{$\begin{array}{c}\text { Moisture content } \\
\theta \mathbf{v} \%\end{array}$} & \multirow{2}{*}{$\begin{array}{l}\mathrm{AW} \\
(\%)\end{array}$} & \multirow{2}{*}{$\begin{array}{c}\text { Bulk } \\
\text { density } \\
\left(\mathrm{g} / \mathrm{cm}^{3}\right)\end{array}$} \\
\hline Sand & Silt & Clay & & FC & WP & & \\
\hline 40.50 & 31.00 & 28.50 & Clay Loam & 31.50 & 15.30 & 15.70 & 1.57 \\
\hline
\end{tabular}

FC = field capacity

WP = wilting point

$\mathrm{AW}=$ available water

b- Chemical properties

\begin{tabular}{|c|c|c|c|c|c|c|c|c|c|c|c|c|c|}
\hline \multirow{2}{*}{$\begin{array}{c}\text { O.M. } \\
(\%)\end{array}$} & \multirow{2}{*}{$\begin{array}{c}\mathrm{CaCO}_{3} \\
(\%)\end{array}$} & \multirow{2}{*}{ pH } & \multirow{2}{*}{$\begin{array}{c}\text { ECe } \\
(\mathbf{d S} / \mathbf{m})\end{array}$} & \multicolumn{7}{|c|}{ Soluble ions $(\mathrm{meq} / \mathrm{L})$} & \multicolumn{3}{|c|}{ Available nutrients (ppm) } \\
\hline & & & & $\begin{array}{l}\mathrm{CO}_{3}+ \\
\mathrm{HCO}_{3}\end{array}$ & $\mathrm{Cl}^{-}$ & $\mathrm{SO}_{4}$ & $\mathbf{C a}$ & Mg & $\mathbf{N a}$ & $\mathbf{K}$ & $\mathbf{N}$ & $\mathbf{P}$ & $\mathbf{K}$ \\
\hline 1.65 & 2.10 & 7.63 & 0.93 & 1.98 & 1.05 & 5.50 & 2.64 & 1.00 & 5.00 & 0.30 & 56.50 & 36.80 & 343.00 \\
\hline
\end{tabular}

Twenty $\mathrm{kg}$ of the soil sample was prepared to the following treatments:

1) Organic fertilizer + bio-fertilizer named as $\mathrm{OB}$

2) Slow release nitrogen fertilizer + organic fertilizer named as SO

3) Fast release nitrogen fertilizer + organic fertilizer named as FO

4)Slow release nitrogen fertilizer + organic fertilizer + bio-fertilizer named as SOB

5) Fast release nitrogen fertilizer + organic fertilizer + bio-fertilizer named as FOB

6) Control (without any fertilization) named as $\mathrm{C}$

Rabbit manure (Table 2) as an organic fertilizer at a rate of $3.5 \mathrm{ton} /$ fed was thoroughly mixed with $250 \mathrm{~g}$ soil sample $(0.88 \mathrm{~g}$ rabbit manure/ $250 \mathrm{~g}$ soil sample). Liquid bio-fertilizer $(10 \mathrm{ml})$ contains both of nitrogen fixers (Azotobacter chroococcum and Azospirillum lipoferum) and phosphate dissolving bacteria (Bacillus polymixa) at a ratio 1:1 was sprayed on surface soil sample upon wetted soil to field capacity.

Two mineral nitrogen fertilizer types(Urea $46.5 \% \mathrm{~N}$ as a fast nitrogen fertilizer, $76 \mathrm{~kg} / \mathrm{fed}$, and ureaform $40 \% \mathrm{~N}$ as a slow nitrogen fertilizer, $87 \mathrm{~kg} / \mathrm{fed}$ ) were separately mixed well with $250 \mathrm{~g}$ of soil sample (19 mg urea or $22 \mathrm{mg}$ ureaform/ $250 \mathrm{~g}$ soil sample). Two hundred and fifty grams from each earlier mentioned treatment were placed into plastic containers. All treatments were subjected to three incubation periods $(14,30$ and 60 days) under laboratory condition $\left(25-30+{ }^{0} \mathrm{C}\right)$. The treatments were organized in a randomized block design with three replications to form an aggregate of 54 exploratory units. The treatments were moistened to the field capacity and their moisture level was monitored and adjusted weekly.

At the end of each incubation period, soil samples were taken to measure total organic carbon (TOC), available phosphorus $\left(\mathrm{P}_{\mathrm{a}}\right)$, total phosphorus $\left(\mathrm{P}_{\mathrm{t}}\right)$, organic phosphorus $\left(\mathrm{P}_{\mathrm{o}}\right)$ and inorganic phosphorus $\left(\mathrm{P}_{\mathrm{i}}\right)$. Available phosphorus was determined by the molybdenum blue colorimetric method (Murphy and Riley, 1962) after extraction by $0.5 \mathrm{M} \mathrm{NaHCO}_{3}(\mathrm{Olsen}$ et al., 1954). Total phosphorus was determined by the same method following perchloric acid $\left(\mathrm{HClO}_{4}\right)$ digestion (Kuo, 1996). Inorganic phosphorus was extracted with $0.5 \mathrm{M} \mathrm{H}_{2} \mathrm{SO}_{4}$ (1:25 soil-to-solution ratio for $16 \mathrm{~h}$ ) and measured by the method of Kuo

Table (2): Some chemical properties of the rabbit manure

\begin{tabular}{|c|c|c|c|c|c|}
\hline pH (1: 2.5) & EC (dS/m) (1:2.5) & $\mathrm{N} \%$ & Organic carbon \% & $\mathrm{K}_{2} \mathrm{O} \%$ & $\mathbf{P}_{2} \mathrm{O}_{5} \%$ \\
\hline 7.10 & 8.40 & 1.00 & 10.60 & 1.00 & 1.38 \\
\hline
\end{tabular}


(1996). Organic phosphorus was calculated as the difference between total P and inorganic P (Gupta and Germida, 1988).Total organic carbon was determined by Walkley \& Black method (Nelson and Sommers, 1982).

\section{RESULTS AND DISCUSSIONS}

The peril of phosphorus wastage from manure treated soils is more related to phosphorus fractions than total phosphorus concentration in manure. Biogeochemical change of different forms of organic and inorganic phosphorus controls soil phosphorus availability (Chen et al., 2003).

\subsection{Fourteen days incubation period.}

Data present in Fig. (1) show the effect of different sources of fertilizers on phosphorus forms after 14 days incubation period. Using various fertilizer sources obviously affected the amount of total $\mathrm{P}$, organic $\mathrm{P}$, inorganic $\mathrm{P}$ and available $\mathrm{P}$. The soil treated with manure and biofertilizer (OB) realized the higher amounts of total $\mathrm{P}$, organic $\mathrm{P}$ and available $\mathrm{P}$ among the other treatments (Fig. 1). These values were almost the same in the control treatment (C). The lower total $P$ values of 221.10 and $219.09 \mathrm{ppm}$ were observed in the soil treated with ureaform + manure + biofertilizer (SOB) and that treated with urea + biofertilizer (FO), respectively. The amount of total $\mathrm{P}$ and organic $\mathrm{P}$ followed the descending order of $\mathrm{OB}>\mathrm{C}>\mathrm{FOB}>\mathrm{SO}>\mathrm{SOB}>\mathrm{FO}$ treatment (Fig. 1). It was observed that the linear trend lines of both total $\mathrm{P}$ and organic $\mathrm{P}$ were running almost parallel to each other with high correlation coefficient value.

$$
\begin{aligned}
& \text { Total } \mathrm{P}=24.12 \mathrm{x}+189.30 \quad\left(\mathrm{R}^{2}=0.944\right) \\
& \text { Organic } \mathrm{P}=27.42 \mathrm{x}+98.00 \quad\left(\mathrm{R}^{2}=0.941\right)
\end{aligned}
$$

The amounts of inorganic $P$ and available $P$ differed from 67.84 to 86.51 and from 25.46 to 36.85 ppm, respectively (Fig. 1). These $\mathrm{P}$ forms followed the descending order of $\mathrm{FO}>\mathrm{FOB}>$ $\mathrm{SOB}>\mathrm{SO}>\mathrm{OB}>\mathrm{C}$ treatment. It was observed that the linear trend lines of both inorganic $\mathrm{P}$ and available $\mathrm{P}$ were running almost parallel to each other with high correlation coefficient value.

$$
\begin{array}{lc}
\text { Inorganic } \mathrm{P}=3.883 \mathrm{x}+66.20 & \left(\mathrm{R}^{2}=0.858\right) \\
\text { Available } \mathrm{P}=2.431 \mathrm{x}+21.46 & \left(\mathrm{R}^{2}=0.852\right)
\end{array}
$$

\subsection{Thirty days incubation period}

The effect of different sources of fertilizers on phosphorus forms after 30 day incubation period is shown in Fig. (2). Using various fertilizer sources clearly affected the amount of total $\mathrm{P}$, organic $\mathrm{P}$, inorganic $\mathrm{P}$ and available $\mathrm{P}$. The soil treated with manure and slow nitrogen fertilizer (SO) realized the higher amounts of total $\mathrm{P}$ and organic $\mathrm{P}$ among the other treatments. The lower values of both total $\mathrm{P}$ (197.65 and $281.40 \mathrm{ppm}$ ) and organic $\mathrm{P}$ (123.53 and $200.92 \mathrm{ppm}$ ) were observed in the soil treated with ureaform + manure + bio-fertilizer (SOB) and that without any treatment $(\mathrm{C})$, respectively.

The amount of total $\mathrm{P}$ and organic $\mathrm{P}$ followed the descending order of $\mathrm{SO}>\mathrm{FO}>\mathrm{OB}$ $>$ FOB $>$ C $>$ SOB treatment (Fig. 2). It was observed that the linear trend lines of both total $\mathrm{P}$ and organic $\mathrm{P}$ were running almost parallel to each other with high correlation coefficient value.

Total $\mathrm{P}=27.37 \mathrm{x}+199.2 \quad\left(\mathrm{R}^{2}=0.870\right)$

Organic $\mathrm{P}=28.84 \mathrm{x}+116.6 \quad\left(\mathrm{R}^{2}=0.914\right)$

The amounts of inorganic $\mathrm{P}$ and available $\mathrm{P}$ differed from 63.90 to 83.33 and from 18.16 to 40.07 ppm, respectively (Fig. 2). The inorganic $\mathrm{P}$ followed the descending order of $\mathrm{FOB}>\mathrm{OB}>\mathrm{FO}$ $>\mathrm{C}>\mathrm{SOB}>\mathrm{SO}$ treatment. The available $\mathrm{P}$ followed the descending order of $\mathrm{OB}>\mathrm{FOB}>\mathrm{SO}$ $>\mathrm{FO}>\mathrm{C}>\mathrm{SOB}$ treatment. It was observed that the linear trend lines of both inorganic $\mathrm{P}$ and available $\mathrm{P}$ were running almost parallel to each other with high correlation coefficient value.

Inorganic $\mathrm{P}=3.44 \mathrm{x}+65.37 \quad\left(\mathrm{R}^{2}=0.770\right)$

Available $\mathrm{P}=3.623 \mathrm{x}+16.29 \quad\left(\mathrm{R}^{2}=0.876\right)$

Sharpley (1985) stated the necessity of adding both carbon (C) and phosphorus (P) source to build up soil $\mathrm{P}$. The $\mathrm{C}$ source provides substrate for microbial growth and activity then microbial turnover results in accumulation of soil organic P. Iyamuremye et al. (1996) found an increase in the available $\mathrm{P}(\mathrm{Pi})$ with manure and alfalfa residues since the Pi realized a value $>0.24 \%$ of total phosphorus. Also, they mentioned that a decrease in $\mathrm{pH}$ value could cause an increase in available $\mathrm{P}$. 3.3. Sixty day incubation period

Data present in Fig. (3) show the effect of different sources of fertilizers on phosphorus forms after 60 days incubation period. Using various fertilizer sources evidently affected the amount of total $\mathrm{P}$, organic $\mathrm{P}$, inorganic $\mathrm{P}$ and available $\mathrm{P}$. The soil treated with slow nitrogen fertilizer and manure (SO) realized the higher amounts of total $\mathrm{P}$ and organic $\mathrm{P}$ among the other treatments. The lower total $\mathrm{P}$ values were observed 


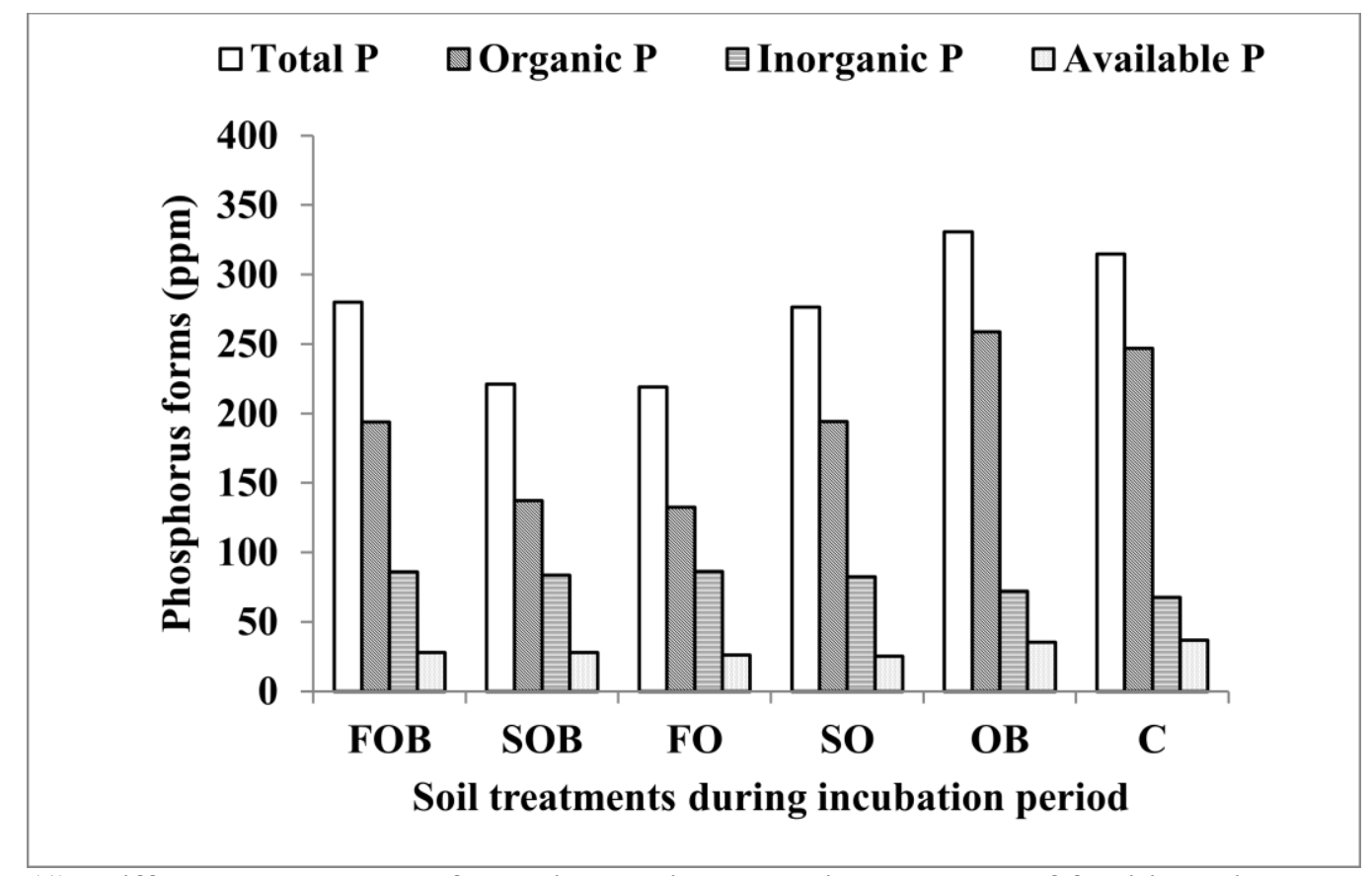

Fig. (1): Different phosphorus forms in relation to various sources of fertilizers in the tested soil after 14 day incubation.

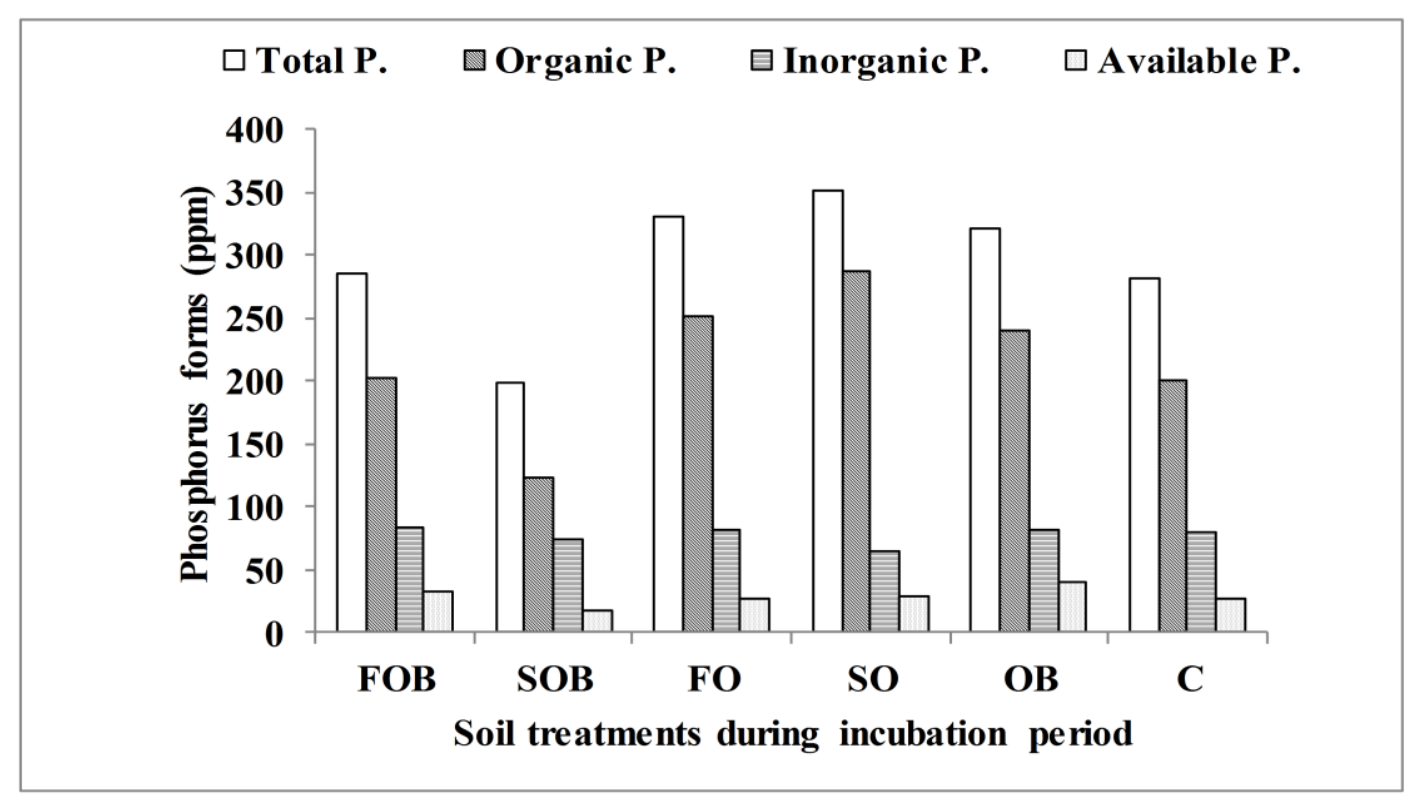

Fig. (2): Different phosphorus forms in relation to various source of fertilizers in the tested soil after 30 day incubation. 


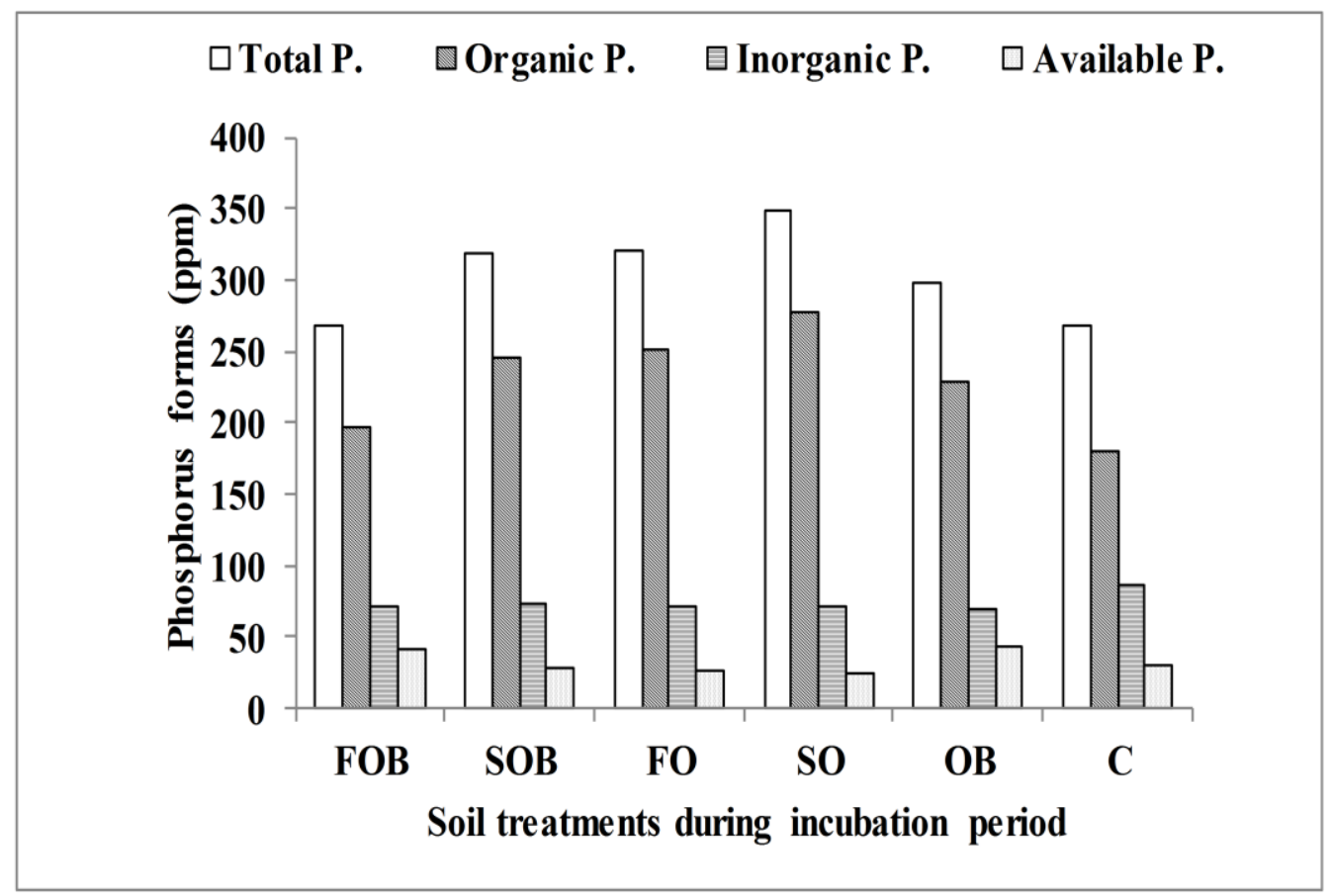

Fig. (3): Different phosphorus forms in relation to various source of fertilizers in the tested soil after 60 day incubation.

in the soil treated with urea+ manure+ biofertilizer (FOB) and the untreated soil (control). The amount of total $\mathrm{P}$ and organic $\mathrm{P}$ followed the descending order of $\mathrm{SO}>\mathrm{FO}>\mathrm{SOB}>\mathrm{OB}>\mathrm{FOB}$ $>$ C treatment (Fig. 3).

Generally, organic phosphorus realized values varied from 67.4 to $79.7 \%$ of the total P (Fig.3). This finding agrees with that obtained by (Chauhan et al., 1979) who stated that the organic $\mathrm{P}$ is known to be sensitive to microbial activity and has a fast turnover. This is because the major component of labile $\mathrm{P}_{\mathrm{o}}$ is a diester $\mathrm{PO}_{4}$, which prevents it from binding strongly to soil minerals and makes it susceptible to rapid mineralization (Tiessen et al., 1984 and Haynes \& Swift, 1988).It was observed that the linear trend lines of both total $\mathrm{P}$ and organic $\mathrm{P}$ were running almost parallel to each other with high correlation coefficient value.

Total $\mathrm{P} \quad=16.67 \mathrm{x}+245.40 \quad\left(\mathrm{R}^{2}=0.948\right)$

Organic $\mathrm{P} \quad=18.90 \mathrm{x}+163.60 \quad\left(\mathrm{R}^{2}=0.973\right)$

The amounts of inorganic $\mathrm{P}$ and available $\mathrm{P}$ differed from 70.02 to 87.35 and from 24.12 to 43.55 ppm, respectively (Fig. 3).The inorganic $\mathrm{P}$ followed the descending order of $\mathrm{C}>\mathrm{SOB}>\mathrm{FO}$ $>\mathrm{SO}>\mathrm{FOB}>\mathrm{OB}$ treatment. The available $\mathrm{P}$ followed the descending order of $\mathrm{OB}>\mathrm{FOB}$ $>\mathrm{C}>\mathrm{SOB}>\mathrm{FO}>\mathrm{SO}$ treatment. It was observed that the linear trend lines of both inorganic $\mathrm{P}$ and available $P$ were running almost parallel to each other with high correlation coefficient value.

$$
\text { Inorganic } \mathrm{P}=2.756 \mathrm{x}+64.33\left(\mathrm{R}^{2}=0.593\right)
$$$$
\text { Available } \mathrm{P}=5.150 \mathrm{x}+17.81\left(\mathrm{R}^{2}=0.874\right)
$$

\subsection{Carbon to phosphorus ratios}

After 14 day incubation period, the low values of $\mathrm{C}: \mathrm{P}$ ratio (28- 30) that resulted from $\mathrm{OB}$ and $\mathrm{C}$ treatments maximized the values of available $\mathrm{P}$ (35.51- $36.85 \mathrm{ppm})$, organic P (247.1 - 258.8 ppm) and total $\mathrm{P}(314.9-331.0 \mathrm{ppm})$ while reduced the value of inorganic $p$ (67.84- 72.19 ppm) and the opposite trend was true (Table 3). Song et al. (2003) reported that at a low C:P ratio, bacteria mobilize more $\mathrm{P}$ than they immobilize and enhance plant $\mathrm{P}$ uptake, while at a high $\mathrm{C}: \mathrm{P}$ ratio bacteria immobilize more $\mathrm{P}$ than they mobilize and inhibit plant $\mathrm{P}$ uptake.

After one-month incubation period, the C:P ratio data were extremely variable by the addition of $\mathrm{N}$ sources with or without bio-fertilizer resulted in differing microbial $\mathrm{C}$ and $\mathrm{P}$ dynamics and ratios. It was observed a decrease in $\mathrm{C}: \mathrm{P}$ ratio with $\mathrm{FO}, \mathrm{SO}$ and $\mathrm{OB}$ treatments due to an increase in 
Table (3): Phosphorus fractions and C: P ratio as affected by different soil treatments.

\begin{tabular}{|c|c|c|c|c|c|c|c|c|c|c|c|c|c|c|c|}
\hline \multirow{3}{*}{ 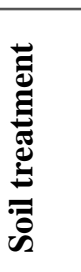 } & \multicolumn{3}{|c|}{$\begin{array}{c}\text { Total } \\
\text { phosphorus(ppm) }\end{array}$} & \multicolumn{3}{|c|}{$\begin{array}{c}\text { Organic } \\
\text { phosphorus(ppm) }\end{array}$} & \multicolumn{3}{|c|}{$\begin{array}{c}\text { Inorganic } \\
\text { phosphorus(ppm) }\end{array}$} & \multicolumn{3}{|c|}{$\begin{array}{c}\text { Available } \\
\text { phosphorus(ppm) }\end{array}$} & \multicolumn{3}{|c|}{ C:P ration } \\
\hline & \multicolumn{15}{|c|}{ incubation period (day) } \\
\hline & 14 & 30 & 60 & 14 & 30 & 60 & 14 & 30 & 60 & 14 & 30 & 60 & 14 & 30 & 60 \\
\hline FOB & 280.1 & 285.4 & 268.0 & 194.0 & 202.1 & 197.2 & 86.0 & 83.3 & 70.8 & 27.9 & 33.0 & 41.9 & 35 & 33 & 35 \\
\hline SOB & 221.1 & 197.7 & 318.9 & 137.4 & 123.5 & 245.0 & 83.7 & 74.1 & 74.0 & 27.9 & 18.2 & 28.8 & 48 & 47 & 31 \\
\hline FO & 219.1 & 331.7 & 321.6 & 132.6 & 250.7 & 250.6 & 86.5 & 80.9 & 71.0 & 26.1 & 27.6 & 26.1 & 45 & 29 & 28 \\
\hline $\mathrm{SO}$ & 276.7 & 351.8 & 348.4 & 194.1 & 287.8 & 277.6 & 82.6 & 63.9 & 70.8 & 25.5 & 27.8 & 24.1 & 38 & 29 & 31 \\
\hline OB & 331.0 & 322.3 & 298.2 & 258.8 & 240.5 & 228.1 & 72.2 & 81.7 & 70.0 & 35.5 & 40.1 & 43.6 & 28 & 29 & 31 \\
\hline $\mathrm{C}$ & 314.9 & 281.4 & 268.0 & 247.1 & 200.9 & 180.6 & 67.8 & 80.5 & 87.4 & 36.9 & 27.3 & 29.5 & 30 & 34 & 34 \\
\hline
\end{tabular}

FOB $=$ fast release nitrogen + organic + bio fertilizers

FO $=$ fast release nitrogen + organic fertilizers

$\mathrm{OB}=$ organic + bio fertilizers
SOB $=$ slow release nitrogen + organic + bio fertilizers $\mathrm{SO}=$ slow release nitrogen + organic fertilizers $\mathrm{C}=$ control without any fertilizer total $\mathrm{P}$ but not $\mathrm{C}$ (Table 3). The highest values of both total $\mathrm{P}(351.8 \mathrm{ppm})$ and available $\mathrm{P}(40.1$ ppm) were recorded at $29 \mathrm{C}: \mathrm{P}$ ratio values. The lowest values of both total $\mathrm{P}(197.7 \mathrm{ppm})$ and available $\mathrm{P}(18.2 \mathrm{ppm})$ were recorded at $47 \mathrm{C}$ : $\mathrm{P}$ ratio (Table 3). Microbial biomass dynamics and $\mathrm{C}: \mathrm{P}$ ratios are important factors regulating nutrient availability (He et al., 1997). Also, they suggested that a decrease in microbial $\mathrm{C}: \mathrm{P}$ ratio is a result of nutrient immobilization but those microbes with a low $\mathrm{C}$ : $\mathrm{P}$ ratios later have a high potential to release $\mathrm{P}$ through microbial turnover. They also found a high correlation of $\mathrm{P}$ uptake by pasture with the sum of $\mathrm{P}$ in the microbial biomass and available pools.

After two months of incubation period, C: $\mathrm{P}$ ratios were lower than those at 14 and 30 day incubation period under $\mathrm{SOB}$ and FO treatments. The $\mathrm{C}$ : $\mathrm{P}$ ratio was higher at $\mathrm{SO}$ treatment than that of FO treatment (Table 3). Available $\mathrm{P}$ increased as the $\mathrm{C}: \mathrm{P}$ ratio increased. The highest values of $\mathrm{C}$ : $\mathrm{P}$ ratio (35) were recorded at (41.94 ppm) available $\mathrm{P}$ value that resulted from $\mathrm{FOB}$ treatment. The lowest values of $\mathrm{C}: \mathrm{P}$ ratio (28) were recorded at $(26.1 \mathrm{ppm})$ available $\mathrm{P}$ value that resulted from FO treatment (Table 3). The reduction of $\mathrm{C}$ : $\mathrm{P}$ ratio and the increase of available phosphorus in this period compared with previous periods of incubation on the ground that bacteria mobilize more $\mathrm{P}$ than they immobilize. It was noticed that the lowest $\mathrm{C}$ : $\mathrm{P}$ ratio and the highest values of available $\mathrm{P}$ were recorded under OB treatment. There are numerous bacteria which can mobilize organic $\mathrm{P}$, and decreasing the ratio of $\mathrm{C}$ : $\mathrm{P}$ may also influence interactions among themselves, which have potential effects on plant $\mathrm{P}$ uptake and should be considered in the future. Recent studies suggest that microbial $\mathrm{C}$ demand is able to drive organic $\mathrm{P}$ mineralization with potential benefits for plants and changing soil $\mathrm{C}: \mathrm{P}$ ratio by adding sugars to the rhizosphere altered microbial biomass phosphorus (MBP) and the available P content in the soil (Marschner, 2007 and Spohn \& Kuzyakov, 2013).

\subsection{Analogous among incubation periods}

In the control treatment, total $\mathrm{P}$, organic $\mathrm{P}$ and available $\mathrm{P}$ were decreased as the incubation period increased while the opposite trend was true for inorganic P (Fig. 4). In FOB treatment (fast release nitrogen + organic + bio fertilizers), total and organic $\mathrm{P}$ increased by increasing incubation period to one month then they decreased when the incubation period reached two months. The inorganic $\mathrm{P}$ decreased as the incubation period increased while the opposite trend was noticed for available P (Fig. 4). The treatments of SOB (slow release nitrogen + organic + bio fertilizers), FO (fast release nitrogen + organic fertilizers) and SO (slow release nitrogen + organic fertilizers) realized an increase in both total and organic $\mathrm{P}$ by increasing the incubation period (Fig. 4). As the incubation period increased, the $\mathrm{SOB}, \mathrm{FO}$ and $\mathrm{SO}$ 

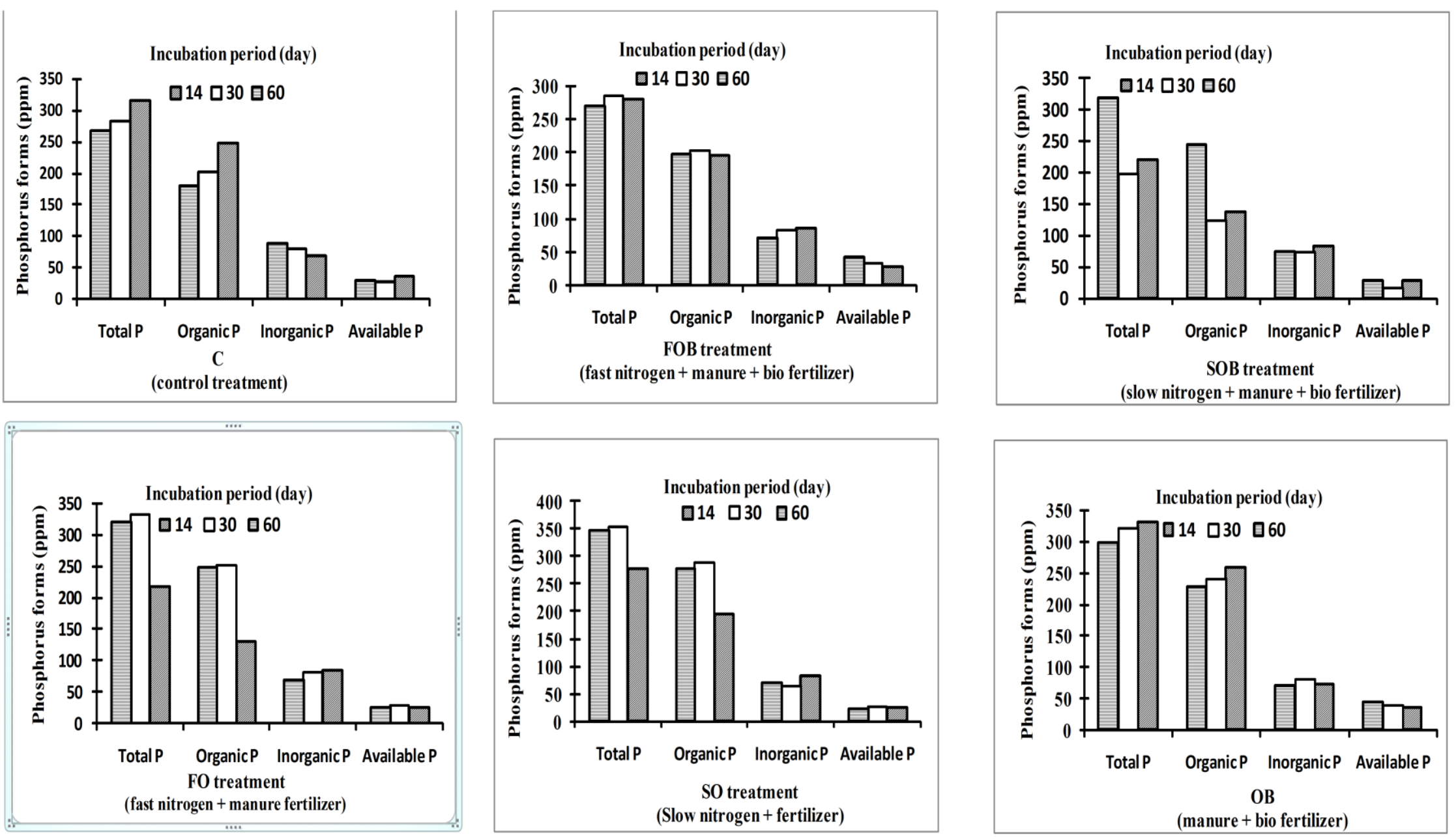

Fig. (4): Different phosphorus forms in relation to various source of fertilizers in the tested soil through different incubation periods. 
treatments decreased the inorganic $\mathrm{P}$ while the available $\mathrm{P}$ remained almost constant. Under the OB treatment (organic + bio fertilizers), both total and organic $\mathrm{P}$ were decreased as the incubation period increased (Fig. 4). The inorganic $\mathrm{P}$ changed slightly and the available $\mathrm{P}$ increased by increasing the incubation period. In general, the data indicated that the average amount of available $\mathrm{P}$ after 30 days incubation period is less than that resulted after 60 days incubation period. The decrease in readily available $\mathrm{P}$ is perhaps an indicative of initial microbial proliferation during the 30 days incubation period.

It might be concluded that the bio-fertilization impact on the release of soil phosphorus where it was slow at the beginning of the incubation period with higher $\mathrm{C}: \mathrm{P}$ ratio. But when time passed as the incubation period increased from 14 to 30 then 60 days with moist soil, activate microorganisms decompose organic matter, thus release phosphorus and increase available phosphorus. This component is necessary for plant growth, also enters into the bio processes within the plant.

\section{REFERENCES}

Chauhan B. S. J., Stewart W. B. and Paul E. A. (1979). Effect of carbon additions on soil labile inorganic, organic and microbially held phosphate. Can. J. Soil Sci. 59: 387396.

Chen G. C., He Z. L.and Huang C. Y. (2000). Microbial biomass phosphorus and its significance in predicting phosphorus availability in red soils. Commun Soil Sci Plant Anal.,31:655-67.

Chen C. R., Condron L. M., Davis M. R. and Sherlock R. R.(2003). Seasonal changes in soil phosphorus and associated microbial properties under adjacent grassland and forest in New Zealand. Forest Ecol. Manage., 177, 539-557.

Cross A.F. and Schlessinger, W.H. (1995). A literature review and evaluation of the Hedley fractionation: Applications to the biogeochemical cycle of soil phosphorus in natural ecosystems. Geoderma, 64: 197-214.

Frossard E., Condron L. M., Oberson A., Sinaj S. and Fardeau J.C. (2000). Processes governing phosphorus availability in temperate soils. J. Environ. Quality, 29: $15-23$.

Guppy C. N., Menzies N. W., Moody P. W. and Blamey F. P. (2005). Competitive sorption reaction between phosphorus and organic matter: are view. Aust. J. Soil Res., 43:189-202.

Gupta V. and Germida J. J.(1988). Distribution of microbial biomass and its activity in different soil aggregate size classes as affected by cultivation. Soil Biol. Biochem. 20, 777-786.

Haynes R. J. and Swift R. S. (1988).Effects of liming and phosphate addition on changes in enzyme activities, microbial biomass and levels of extractable nitrogen, sulfur, and phosphorus in an acid soil. Boil. Fertil. Soil 6: 153-158

He Z. L., Wu J., O’Donnell A. G. and Syers J. K.(1997). Seasonal responses in microbial carbon, phosphorus and sulphur in soils under pasture. Biol. Fertil. Soils 24: 421428.

Hue N. V., Ikawa, H. and Silva, J. A. (1994). Increasing plant-availability phosphorus in an Ultisol with a yard-waste compost. Commun Soil Sci. Plant Anal.20:3291303.

Iyamuremye F., Dick R. P. and Baham J. (1996).Organic amendments and phosphorus dynamics: II. Distribution of soil phosphorus fractions. Soil Sci., 161: 436-443.

Kashem A., Akinremi O. O. andRacz G. J. (2004). Phosphorus fractions in soil amended with organic and inorganic phosphorus sources. Can. J. Soil Sci., 84:83-90.

Khan K. S. and Joergensen R.G. (2009). Changes in microbial biomass and $\mathrm{P}$ fractions in biogenic household waste compost amended with inorganic $\mathrm{P}$ fertilizers. Bioresource Tech., 100: 303-309.

Klute A. (1986). Methods of Soil Analysis. Part 1: Physical and mineralogical methods (2nd edition). American Society of A gronomy Inc., Madison, Wisconsin, USA.

Kuo S.(1996). Phosphorus. In: Sparks, D.L. (Ed.), Methods of Soil Analysis. Part 3: Chemical Methods. Soil Sci. Soc. of America, Inc. pp. 869-919. Madison, WI, USA. 
Marschner P. (2007). Plant microbe interactions in the rhizosphere and nutrient cycling. In: Nutrient cycling in terrestrial ecosystems, soil biology series. Marschner P, Rengel Z, (eds). Springer; Heidelberg: Germany p. $159-182$.

Marschner P. (2008). The role of rhizosphere microorganisms in relation to $\mathrm{P}$ uptake by plants. In: The ecophysiology of plantphosphorus interactions. White PJ, Hammond JP, (eds) Springer; Heidelberg, p. $165-176$.

Murphy J. and Riley J. P.(1962). A modified single solution method for the determination of phosphate in natural waters. Anal. Chim, Acta. 26: 31-36.

Nelson D. W. and Sommers L. E. (1982).Total carbon, organic carbon and organic matter. pp. 539-577. In: Methods of soil analysis. Part 2: Chemical and microbiological properties. A. L. Page, R. H. Miller, and D. R. Keeney (eds.). American Society of Agronomy Madison, WI, USA,

Olsen S. R., Cole C. V., Watanabe E. S. and Dean L. A.(1954). Estimation of available phosphorus in soils by extraction with sodium bicarbonate. U. S. Dept. Agric. Circ. 939

Page A. L. (1982). Methods of Soil analysis. Part 2: Chemical and microbiological properties, (2nd Ed). Inc. Soil Sci. Soc. of Am., Madison, Wisconsin, USA.

Quiquampoix H. and Mousain D. (2005). Enzymatic hydrolysis of organic phosphorus. In: Organic phosphorus in the environment, (eds B.Turner, E. Frossard and D. Baldwin), Chapter 5 pp. 89-112. CABI Publishing, Wallingford, UK.

Redel Y. D., Escudey M., Alvear M., Conrad J. and Borie, F. (2011). Effects of tillage and crop rotation on chemical phosphorus forms and some related biological activities in a Chilean ultisol. Soil Use Manage, 27: 221-228.
Richardson A. E., George T.S., Hens M. and Simpson R.J. (2005). Utilization of soil organic phosphorus by higher plants. In: Organic phosphorus in the environment, (eds B. Turner, E. Frossard and D. Baldwin), Chapter 8pp. 165-184. CABI Publishing, Wallingford, UK.

Sharpley A. N.(1985). Phosphorus cycling in unfertilized and fertilized agricultural soils. Soil Sci. Soc. Am. J. 49: 905-911.

Song Q. H., Li, F. M., Liu H. S., Wang J. and Li, S. Q. (2003). Effect of plastic film mulching on soil microbial biomass in spring wheat field in semi-arid loess area. Chin J. Appl. Ecol.,14:1512-1516.

Spohn M. and Kuzyakov Y. (2013). Phosphorus mineralization can be driven by microbial need for carbon. Soil BiolBiochem. 61:69-75.

Stevenson F. J. (1986). Cycles of soil carbon, nitrogen, phosphorus, sulfur, micronutrients. New York: Wiley, USA.

Tiessen H., Stewart J. W. B. and Cole C. V.(1984) Pathways of phosphorus transformation in soils of differing pedogenessis. Soil Sci. Soc. Am. J. 48: 853-858.

Turner B. L. and Engelbrecht B. M. (2011). Soil organic phosphorus in lowland tropical forests. Biogeochem., 103:297-315.

Turner B. L., Frossard E. and Baldwin D.S. (2005).Preface. In: Organic Phosphorus in the Environment (eds B. Turner, E. Frossard ad D. Baldwin), pp. ix-x. CABI Publishing, Wallingford, UK.

Vincent A. G., Turner B. L. and Tanner E. V. J. (2010). Soil organic phosphorus dynamics following perturbation of litter cycling in a tropical moist forest. Eur. J. Soil. Sci. 61:48-57.

Zhou Q., Gibson C. E. and Zhu Y. (2001). Evaluation of phosphorus bioavailability in sediments of three contrasting lakes in China and the UK. Chemosphere. 42: 221-225. 


\section{صور الفوسفور في التربة المعاملة بالأسمدة العضوية والتتروجينية والحيوية خلال فترات تحضين مختلفة مصطفي يونس خلف لله - ياسر عبد العال سيد$$
\text { قسم علوم الأر اضسى والمباهـ كلبة الزراعة- جامعة الأزهر - أسبوط- مصر. }
$$

يرتبط فقد الفوسفور من التربة بإجزاء الفوسفور اكثر من تركيزه الكلي في السماد. ويتحكم التغير الكميائي الحيوي

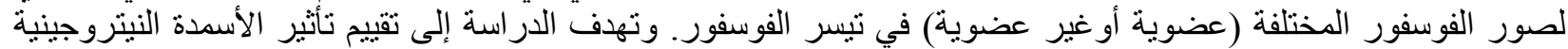

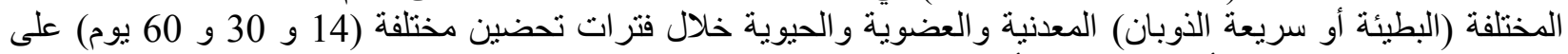

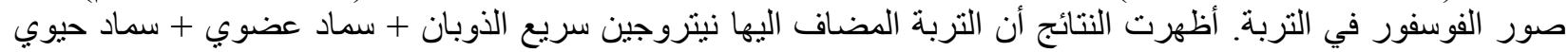

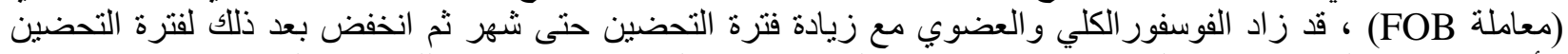

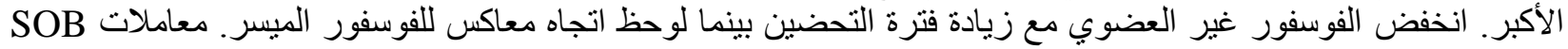

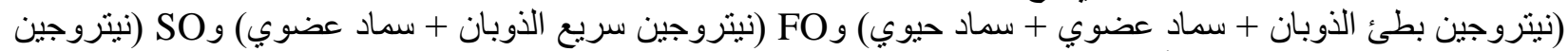

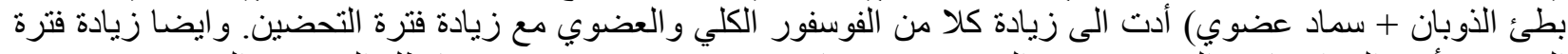

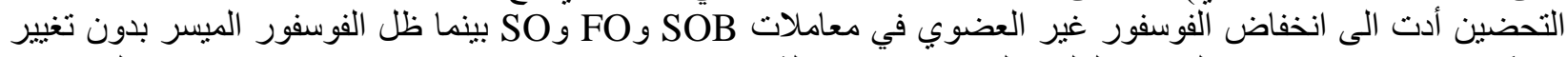

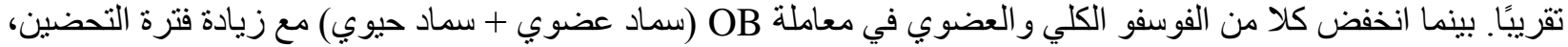
وتغير الفوسفورغير العضوي بشكل طفيف وز اد الفوسفور الميسر بزيادة فترة التحضين. بعد فترة التحضين التحبين لمدة 14 يوم ،

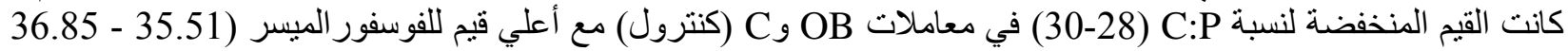

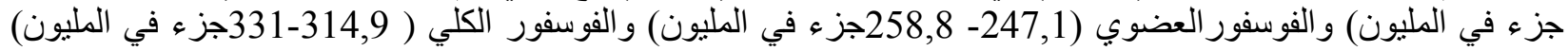

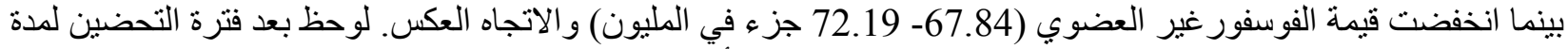

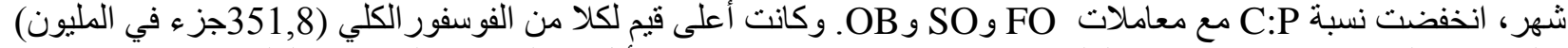

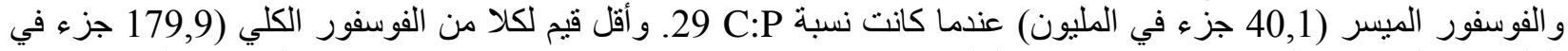

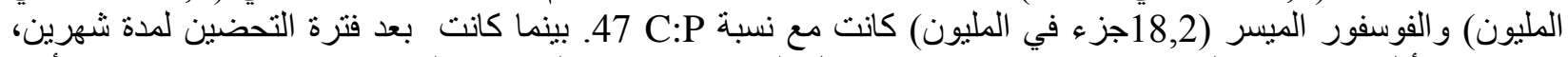

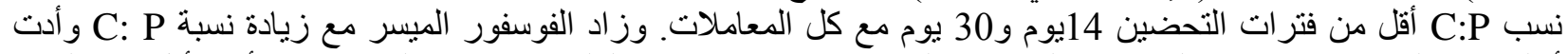

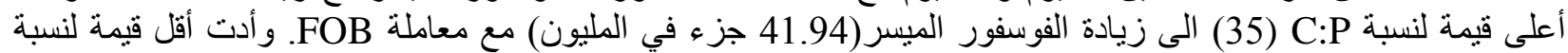

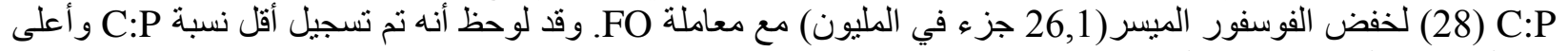

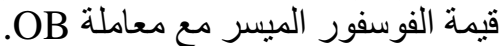

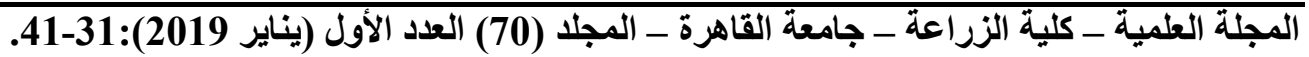

